\title{
Responsibility of Manufacturers in Waste Management of Plastic Packaged Drink Products Based on Law Number 18 of 2008 Regarding Waste Management (Case Study in Ambon City, Maluku Province)
}

\author{
La Ode Angga*, Dyah Ridhul Airin Datie, Popi Tuhulele, Sabri Fataruba, Iqbal Taufiq \\ Faculty of Law, Pattimura University, Ambon 97233, Indonesia
}

Corresponding Author Email: laodeangga@yahoo.com

https://doi.org/10.18280/ijsdp.160212

Received: 3 August 2020

Accepted: 12 January 2021

\section{Keywords:}

waste management, responsibilities, manufacturers

\begin{abstract}
This article is motivated by the large number of irresponsible use of plastic waste in Ambon city, Maluku Province. This research is a normative legal research. The results obtained in this paper are Waste Management of plastic packaging beverage products carried out by Ambon city producers in accordance with Law Number 18 of 2008 concerning Waste. Management to reclaim packaging that has been consumed by consumers so that they can be recycled systematically, thoroughly and in a sustainable manner. and produce goods using materials that are environmentally friendly and reusable. Apart from doing this, producers are also responsible for waste management in collaboration with the Ambon City Government as stated in Article 44 paragraph (1) of Ambon City Regulation Number 11 of 2015 which includes the provision / construction of Temporary Shelters (TPS) or TPS 3R. (Reduce Reuse). Recycling), Final Disposal Site (TPA) or Integrated Waste Processing Site (TPST), as well as supporting facilities and infrastructure, in this case providing a vehicle for transporting waste from TPS or TPS 3R to TPA or TPST, TPA or TPST management and / or management other processed products. This cooperation takes the form of sorting, collecting, transporting, processing, and / or final processing of waste.
\end{abstract}

\section{INTRODUCTION}

Law Number 32 of 2009 concerning Environmental Protection and Management of the State Gazette of the Republic of Indonesia of 2009 Number 140 (UUPPLH-2009), has the following provisions [1]:

a. Environmental management based on the preservation of a harmonious and balanced environmental capacity to support sustainable development for improving human welfare.

b. Everyone has the right to a good and healthy environment, and is obliged to preserve the environment and prevent and overcome environmental damage and pollution.

c. Everyone has the right and obligation to participate in the framework of environmental management.

d. Efforts to develop the environment do not take place in isolation. However, as a member of the world community, the pace of business in the environmental field must have meaning for the life of a nation.

e. Environmental management requires the development of a system with integration as its main feature.

The cause of pollution and environmental damage is one of them is rubbish, rubbish is the remnants of materials that have been treated either because they have already taken the main part or because of processing or because there are no benefits in terms of socio-economic aspects that are worthless and in terms of the environment can cause pollution or disruption to the environment [2]. According to Article 1 paragraph (1) of Law Number 18 Year 2008 Regarding Waste Management of
State Gazette of the Republic of Indonesia Year 2008 Number 69 that waste is the residue of human daily activities and / or solid natural processes [3].

The source of waste can come from the community in general, which is directly related to population growth that continues to increase [4]. Increasing the number of residents, it will lead to new settlements supported by technological advances, then the volume of waste will also increase in tune with the human activities, so that if handling and management is not good will cause major problems in environmental conservation [5].

Based on the origin of waste materials are divided into two types, namely organic and inorganic waste [6].

a. Organic Waste Organic waste is food scraps such as meat, fruit, vegetables and so on. Examples of rubbish from inorganic substances are: pieces / plates of metal, various types of rocks, broken pieces of glass, bones, bones, and others. This type of rubbish, seeing that it is physically hard is good for elevating low land or it can also be used to expand the trail. But if diligently working on metal waste can be re-melted to become useful goods, rocks to confine low soil or harden paths, broken glass can be re-melted and used as useful items, and bones if mashed (and processed) can for fertilizer and others.

b. Inorganic waste Inorganic waste is the remaining synthetic material such as plastic, paper, metal, glass, ceramics and so on.

Plastic waste contains artificial inorganic materials made up of chemicals that are quite dangerous for the environment. 
Waste from plastic is very difficult to be deciphered naturally [7]. To decompose plastic waste itself requires approximately 80 years to be completely degraded. Therefore the use of plastic material can be said to be unfriendly or conservative for the environment if used without using certain restrictions. Suwerda put forward several impacts if the waste is not managed properly as follows [8]:

a. Garbage can be a source of disease, the environment becomes dirty. This will become a fertile place for pathogenic microorganisms that are harmful to human health, and also a nest of flies, rats and other wild animals.

b. Combustion of garbage can result in air pollution that can disturb public health, and trigger global warming.

c. Waste spoilage can cause unpleasant odors and is harmful to health. Discharged liquid can seep into the ground, and can cause pollution of wells, ground water, and which is discharged into water bodies will pollute rivers.

d. Disposing of river waste or water bodies can cause river siltation, which can trigger floods.

The Waste Management Act is a legal rule that can be used as a legal basis for waste management in Indonesia. In addition to the Waste Management Law, there are other regulations governing waste management, including the UUPPLH [1] Government Regulation Number 81 of 2012 concerning Management of Household Waste and Household Solid Waste and several regional regulations that have been established by the local government both at the Regency level or City as in Ambon City Regulation Number 11 Year 2015 Regarding Waste Management [9].

According to the Waste Management Act in Article 1 number (5) states that waste management is a systematic, comprehensive and sustainable activity that includes the reduction and handling of waste. As for the Waste Management Act in Article 3 states that the principle of waste management based on this law is that waste management is carried out based on the principles of responsibility, sustainable principles, principles of justice, principles of awareness, principles of togetherness, principles of safety, principles of security, and the principle of economic value. While Article 4 of the Waste Management Law states that management is aimed at improving public health and environmental quality and making waste a resource.

Waste management is inseparable from the products sold by businesses that are consumed by the community. Government Regulation Number 81 Year 2012 Concerning Management of Household Waste and Similar Trash Household Waste The Republic of Indonesia State Gazette Year 2012 Number 188 (abbreviated as Government Regulation Number 81 Year 2012) in Article 12 technically requires producers to limit waste generation. What is intended by limitation of waste generation in this Government Regulation is an effort to minimize waste generation that is carried out from before the production of a product and /or product packaging until the end of the use of the product and /or product packaging [9].

The Waste Management Law in Article 15 states that producers are required to manage the packaging and /or goods they produce which cannot or are difficult to decompose by natural processes. With this regulation, it certainly helps to reduce the amount of garbage generated, especially plastic packaging drinks. However, in reality for Ambon city direct waste management is generally managed by the Ambon City Environmental and Waste Management Office, which is centered at the Final Disposal Site (TPA) [10], which is managed by the Integrated Waste Management Installation (IPST) located in Toisapu, AmaOry Village, in the rule is that the producer is also responsible for the management of products that are released, especially products that are distributed or sold in the city of Ambon. IPST Toisapu itself has difficulty in managing all the garbage that has been collected in the landfill because the amount of waste continues to increase, especially plastic waste and added with no process of sorting waste from temporary shelters (TPS). Therefore, the issuance of a regulation requiring producers to manage the packaging and /or goods they produce that cannot or is difficult to decompose by natural processes in order to assist the government in reducing and overcoming the amount of plastic waste that exists. Based on the background above, the problem in this paper is: "What are the Implications of the Responsibilities of Producers of Plastic Packaged Drink Products in Ambon City in Waste Management Based on Law Number 18 Year 2018 Regarding Waste Management? Research Methods; The type of writing used in this writing is normative juridical, i.e. by identifying legal issues that develop in society, examining the applications of law in society, reviewing positive legal provisions and legal principles and doctrines to clarify the results of research, then reviewed aspects practical and academic aspects of legal science in legal research [11].

\section{LITERATURE REVIEW}

\subsection{Theoretical framework}

\subsubsection{The State of Welfare Law (Walfare State)}

The State Utilization Theory as a Big Theory used in this paper with an argument about the state (Local Government) in terms of the utilization of waste management in Ambon City. (Local government) must be present in waste management in Ambon City. In the theory of the welfare state, which reflects the duties of the state or government or local government in carrying out the public interest, it becomes very broad, so that the Ambon City Government must be present in terms of waste management.

The birth of the state theory supported the reaction against the failure of the classical rule of law concept (night watch state) and socialist rule of law. Both the concept and the type of rule of law have different bases and forms of state control over economic resources. Theoretically, these differences are motivated and changed by the ideology or understanding they hold. In classical liberal law the state is driven by an understanding of liberalism or the classical rule of law, while the socialist legal state understands Marxism [12]. For a country that wants a wealth law like Indonesia, everyone agrees with Pancasila and Article 33 paragraph (3) of the 1945 Constitution of the Republic of Indonesia.

\subsection{Theories of development sustainable urban}

Graham Haughton and Colin Hunter [13] emphasize three basic principles of sustainable city development, namely:

a. The principle of intergenerational equity which is the principle of sustainable development with a future orientation.

b. The principle of social justice (social justice) in the gap of access and distribution of natural resources 
intragenerasi to reduce poverty which is considered a factor of environmental degradation.

c. The principle of transfrontier responsibility that guarantees a minimal shift in geographic environmental impact with compensation efforts. In the urban context it is expected that excessive use of natural resources and degradation of the quality of the environment in areas outside of the city concerned will have an impact on the rate of growth.

The Indonesia Decentralized Environmental [14] and Natural Resources Management Project (IDEN) workshop and the Urban and Regional Development Institute (URDI) also proposed several principles of sustainable city development in Indonesia, some of which are in line with those expressed by Graham Haughton et al. The following principles need to be adjusted to local conditions (source: Appendix F, Workshop Materials, Strengthening Action for Sustainable Urban Development in Indonesia, Final Report of Preparation Phase [16]. Collaboration between the Indonesia Decentralized Environmental \& Natural Resources Management Project (IDEN) and Urban and Regional Development Institute (URDI), and active participation from other related institutions / parties, December 2004) [13]:

a. Having a long-term vision, mission and strategy that is realized consistently and continuously through plans, programs and budgets along with participatory incentive-disincentive mechanisms.

b. Integrate efforts for economic growth with the realization of social justice, environmental sustainability, community participation and cultural diversity.

c. Develop and strengthen cooperation and partnerships among stakeholders, between sectors and between regions.

d. Maintain, develop, and use wisely local resources and gradually reduce dependence on external (global) and non-renewable resources.

e. Minimizing the ecological footprint (ecological footprint) of a city and maintaining and even increasing the local ecological carrying capacity.

f. Applying social justice and developing public awareness of consumption patterns and environmentally friendly lifestyles for the benefit of future generations

g. Providing a sense of security and protecting public rights.

h. Fair compliance with the law.

i. Creating a conducive climate that encourages learning societies to continuously improve the quality of life.

Related to the pillars of sustainable development, the concept of sustainable city development is also based on four main pillars, namely the economic, social and environmental dimensions supported by the pillars of governance. The governance pillar as a set of governance, implementation and control tools is elaborated as a principle of $5 \mathrm{R}$ analysis, including [13]:

1. Obligations and responsibilities (responsibility) to implement and implement sustainable city development.

2. Right (right) to carry out policies and programs for sustainable city development that are of public interest at large.

3. Risk, as a consideration for making sustainable city development decisions now and in the future.

4. The benefits (revenue) of implementing policies and programs for sustainable city development for the public now and in the future.

5. Relations (relations), as a manifestation of stakeholder coordination to optimize the realization of sustainable city development.

Munasinghe elaborates on the three main pillar elements, namely the economic pillar by the elements of growth, efficiency, and stability; social pillars by elements of empowerment, participation, and institutions; and environmental pillars by elements of diversity, natural resources and pollution (Figure 1).

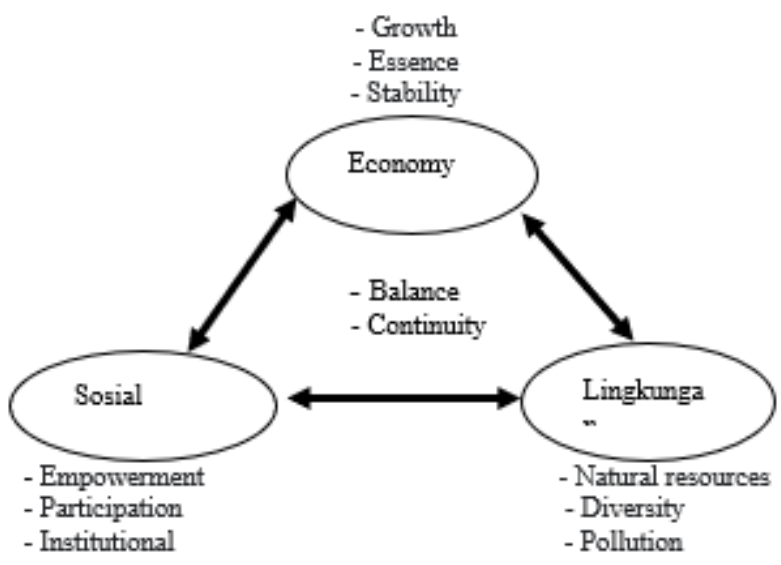

Figure 1. The three main pillars of environmental protection and management

Image: Basic Element Diagram of Sustainable Development Sources: Sources: Munasinghe, M., Sustainable Development Triangle, 'Sustainable Development', edited by Cleveland [13].

As a process, sustainable city development represents the progress of gradual changes that take place continuously (loop system) with directions to better quality based on the feedback stages that are passed. Christopher A. Haines stated it as a city transformation process with benchmarks that indicate changes, namely natural resource conservation, rehabilitation for conservation and preservation, providing public transportation services, and controlling urban sprawl. The transformation towards sustainable city development by the Indonesian SUD Forum was translated through a more assertive benchmark of difference. If development is initially fully oriented towards economic growth, then sustainable development requires ecological sustainability, where in the next cycle it is balanced with social justice and subsequently with cultural preservation. As a continuous transformation process, the development cycle will continually improve the values of sustainability. Although the value of sustainability cannot ideally be determined, the essence of the sustainability process is the values of better appreciation of improving the quality of economic, social and environmental life. The following figure illustrates the progress of sustainability values that should be achieved in each phase of development [13]

\section{METHODOLOGY}

The research to be conducted is research on "normative law" [11]. The first step is to conduct legal research normative 
based on an inventory of primary, secondary and tertiary laws relating to the environment, Civil Law, and limited company law. This research seeks a clear legal basis in laying the foundation in the perspective of civil law [16]. In this study using a sculpture approach and conceptual approach [13].

\section{RESULTS AND DISCUSSION}

\subsection{Responsibility of producers for environmental pollution in ambon city}

In principle, environmental pollution is a danger that always threatens environmental sustainability from time to time. Ecosystems from an environment can be disturbed because of environmental pollution [17]. According to Sutamihardja, pollution is the addition of various materials as a result of human activities to the environment and usually exerts a harmful influence on the environment [18].

According to Article 22 paragraph (1) UUPPLH-2009 states that every business and / or activity that has a significant impact on the environment must have an EIA [1]. Impact criteria specified in this Article include the extent of the impact area, the intensity and duration of the impact, and the number of other environmental components that will be affected. The criteria for businesses and / or activities with significant impacts that must be accompanied by environmental impact analysis include processes and activities whose results can affect the natural environment, the artificial environment, and the social and cultural environment. What is meant by EIA is a study of the significant impacts of a planned business and / or activity on the environment needed for making decisions about the conduct of a business and / or activity [19]. In principle Amdal is a preventive instrument in overcoming the problem of environmental pollution. Through EIA documents it can be seen whether a business or activity has the potential to have an impact or not, if it has a large impact, especially negative money, of course the business or activity may not operate or may operate with certain requirements so that the negative impact can be reduced to the point of endangering the environment [20].

Based on Article 15 of the Waste Management Law, producers in carrying out production activities should generate as little waste as possible, can be reused, can be recycled, and / or easily decomposed by natural processes. What is intended by managing packaging is that in the process of managing such waste, producers can withdraw packaging for recycling and / or reuse. What is meant by production material in this explanation is in the form of raw materials, supporting materials, supplementary materials, or product packaging that will be used.

According to Government Regulation Number 81 Year 2012 concerning producer responsibility includes, in Article 12 that Producers are obliged to limit waste generation by preparing plans and / or programs to limit waste generation as part of their business and /or activities and / or producing products using packaging which is easily decomposed by natural processes and which causes as little waste as possible [9]. Article 13 Producers are obliged to carry out waste recycling by compiling a waste recycling program as part of their business and / or activities using production raw materials that can be recycled and / or withdrawing waste from products and product packaging for recycling. In carrying out recycling, producers may appoint other parties who are required to have a business license and / or activity. Furthermore, in Article 14 producers must reuse waste by preparing plans and / or programs to reuse waste as part of their business and / or activities in accordance with policies and strategies for managing waste including using production raw materials that can be reused and / or recalling waste of products and product packaging for reuse [9].

According to the Ambon City Regulation Number 11 Year 2015 Regarding the Management of the State Gazette of the Republic of Indonesia Year 2015 Number 11, in Article 29 states [21]:

(1) Business actors must carry out:

a. waste reduction from business activities; and

b. handling waste in an environmentally sound manner.

(2) Waste reduction from business activities as referred to in paragraph (1) letter a is carried out through:

a. application of clean and non-waste technology (an ethical, economic, efficient and effective objective for any treatment process that does not produce waste);

b. application of recycling technology that is safe for health and the environment; and

c. help the efforts to reduce and use the Regional Government and the community.

(3) Waste handling as referred to in paragraph (1) letter b shall be carried out by:

a. producing environmentally friendly products and packaging;

b. environmental management in a unified production process;

c. waste segregation;

d. payment of compensation for processing costs for packaging that cannot be recycled with current technology, through social and environmental responsibility;

e. the application of waste processing mechanisms arising from the production activities carried out;

f. utilization of waste to produce products and energy;

g. optimizing the use of recycled materials as product raw materials; and

h. accommodate product packaging that has been utilized by consumers.

Producers in particular in the city of Ambon have been given responsibilities or obligations in accordance with those described in the rules, including the UUPLH Article 22 paragraph (1), Waste Management Act Article 15, Government Regulation Number 81 Year 2012 pPasal 12, Article 13 , Article 14, and Ambon City Regional Regulation article 29. These responsibilities or obligations are borne by producers in order to prevent environmental pollution caused by the production of a product that uses materials that are difficult to decompose or are not easily recycled. However, when producers do not carry out these obligations it will have an impact on environmental pollution, then the producers must be responsible in accordance with the provisions set.

In the event of an impact on environmental pollution, according to Article 87 paragraph (1) of the UUPPLH [1]:

"Every party responsible for a business and / or activity that commits an illegal act in the form of pollution and / or environmental damage that causes harm to other people or the environment must pay compensation and / or take certain actions."

According to the Regulation of the Minister of Environment 
of the Republic of Indonesia Number 7 of 2014 concerning Environmental Losses due to Pollution and / or Environmental Damage State Gazette of the Republic of Indonesia of the Ministry of Environment Number 1726 of 2014 (abbreviated to the Minister of Environment Regulation) in Article 1 number 2 states that the Losses The environment is a loss arising from pollution and / or environmental damage that is not a private property. Then in the Ministerial Regulation explained in Article 3 relating to the intended losses include [22]:

a. losses due to exceeding the Environmental Quality Standards as a result of not carrying out all or part of the obligations of wastewater treatment, emissions, and / or waste management of hazardous and toxic materials;

b. losses for reimbursing the costs of carrying out environmental dispute resolution, including costs: field verification, laboratory analysis, experts and supervision of the implementation of payment of environmental losses;

c. loss to compensate for the cost of handling pollution and / or environmental damage and environmental recovery; and / or

d. ecosystem loss.

Based on Article 3 letter $\mathrm{c}$ of the Regulation of the Minister of Environment, the stages of restoration of environmental functions include remediation, rehabilitation and restoration. Remediation is an effort to restore environmental pollution to improve the quality of the environment, rehabilitation is a recovery effort to restore the value, function and benefits of the environment including efforts to prevent damage to the land, provide protection, and improve the ecosystem, then restoration is a recovery effort to make the environment or the parts function again as before.

In civil law regulates compensation due to acts against the law. What is intended by an act that violates the law is an act committed by one or more parties that has harmed the other party. Acts that violate the law carried out by one party or preferably done intentionally or unintentionally will certainly harm the other party whose rights have been violated.

Based on Article 1365 of the Civil Code, an act against the law is an act that violates the law, decency, public interest, and propriety. Producers in their responsibility for waste management can partner with local governments as contained in Article 44 paragraph (1) of Ambon City Regulation. Then the scope of the partnership includes collecting waste service fees, providing / building Temporary Shelter (TPS) or TPS 3R (Reduce Reuse, Recycling), Final Disposal Site (TPA) or Integrated Waste Processing Site (TPST), as well as supporting facilities and infrastructure, transportation waste from TPS or TPS 3R to TPA or TPST, TPA or TPST [23] management and / or other processed product management. The partnership is in the form of sorting, collecting, transporting, processing and / or final processing of waste. In terms of the responsibilities that have been explained, Ambon City producers must carry out absolute responsibility which includes:

a. Pay compensation for the prevention of pollution and / or environmental damage and environmental recovery.

b. Partnering with the Ambon City Government in terms of providing facilities and infrastructure in support of carrying out transportation and processing activities.

c. Producers can withdraw packaging for recycling and / or reuse. d. Reducing the number of products to be produced in order to reduce the amount of waste plastic beverage packaging every day

In terms of the accountability, the writer has conducted an interview at the IPST location in the results of the interview that the producers in Ambon City themselves did not take responsibility for the environmental pollution caused by plastic packaging waste that they produce in terms of packaging that is not easily decomposed by nature and continues to increase in its production. The interview data was taken from the IPST location because when the writer will do an interview at the producer of plastic beverage packaging namely CV. Supen Inti Perkasa (AISO) having its address at Jl. Mataina No. 8-9 Waistopong Hamlet, Amahusu Village, Ambon City and CV. AbadiTigaMandiri (AYUDES) having its address at Jl. Drs. Hi TaherMidziTaher, BatuMerah, Sirimau, Ambon City, the two producers were not willing to be interviewed or to collect data relating to waste management of products that have been produced [24].

\subsection{Implications of the management of plastic packaging drinking waste by producers in ambon city based on law number 18 year 2008 regarding waste management}

The Law on Waste Management helps to reduce the amount of waste, especially plastic packaging drinks. The intended waste management is systematic management by taking into account the Principles and Objectives contained in the intended regulation namely the Principle in Article 3 "Waste Management is conducted based on the principle of responsibility, sustainable principle, principle of benefit, principle of justice, principle of awareness, principle of togetherness, principle of safety , the principle of security and economic value expectations. "While the aim in Article 4 is that "Waste management aims to improve public health and environmental quality and make waste a resource".

Furthermore, the principle of waste management referred to in the explanation of the Waste Management Law is as follows [25]:

a. What is meant by the principle of "responsibility" is that the Government and regional governments have the responsibility of managing waste in realizing community rights to a good and healthy environment as mandated in Article 28H paragraph (1) of the 1945 Constitution of the Republic of Indonesia.

b. What is meant by the principle of "sustainable" is that waste management is carried out using environmentally friendly methods and techniques so that it does not cause negative impacts on public health and the environment, both in the present generation and in future generations.

c. What is meant by the principle of "benefit" is that waste management needs to use an approach that considers waste as a resource that can be utilized to meet the needs of the community.

d. What is meant by the principle of "justice" is that in waste management, the Government and regional governments provide equal opportunities to the community and business world to play an active role in waste management.

e. What is meant by the principle of "awareness" is that in waste management, the Government and regional governments encourage everyone to have an attitude, 
concern, and awareness to reduce and deal with the waste they produce.

f. What is meant by the principle of "togetherness" is that waste management is carried out by involving all stakeholders.

g. What is meant by the principle of "safety" is that waste management must guarantee human safety.

h. What is meant by the principle of "security" is that waste management must guarantee and protect the community from various negative impacts.

i. What is meant by the principle of "economic value" is that waste is a resource that has economic value that can be utilized so as to provide added value.

The Ministry of Environment and Forestry (KLHK) considers that the waste problem is already troubling. Indonesia is even ranked second in the world as a producer of plastic waste to the Sea which reached 187.2 million tons after China which reached 262.9 million tons. In third place are the Philippines which produces 83.4 million tons of plastic waste into the sea, followed by Vietnam which reaches 55.9 million tons, and Sri Lanka which reaches 14.6 million tons per year. KLHK aims to reduce plastic waste by more than 1.9 million tons by 2019.

Director General of Waste Management, Waste, and B3 of KLHK TutiHendrawatiMintarsih said that the total amount of Indonesian waste in 2019 will reach 68 million tons, and plastic waste is expected to reach 9.52 million tons or 14 percent of the total waste. Meanwhile, according to Corry Manulang, a researcher in the marine pollution sector of the Indonesian Institute of Sciences (LIPI) Ambon stated that 70 percent of rubbish in Ambon Bay is dominated by plastic waste such as plastic bags and plastic beverage bottles [26]. Corry and friends have been doing their research since 2017, the waste research conducted is focused on three locations in the city of Ambon, namely PLN Poka, KamiriWayame village, and the Tantui area. Every month it takes waste samples at these three locations. Until now 11 times data collection and waste collection have been carried out at the same tidal conditions every month and at the same point. The rubbish is transported in sacks and analyzed more than 70 percent of the rubbish in the bay is plastic rubbish, even researching the smallest micro plastic rubbish that can be eaten by marine biota [24].

From these results, the involvement of producers in the city of Ambon in processing waste or reducing waste generation must be done. The waste management must be carried out systematically, thoroughly, and continuously, if the waste management is not carried out by the producers in a systematic, comprehensive, and sustainable manner then it will be able to cause various pollution which include [7]:
a. Land Pollution
b. b. Sea Pollution
c. Water pollution

Preventing environmental pollution from occurring, producers must carry out systematic, comprehensive and sustainable waste management as a precautionary measure and control pollution and / or damage and restoration of environmental functions. Producers can partner with the Ambon City Government in particular the Ambon City Waste and Waste Agency to make waste reduction and mitigation so that it can facilitate the process of managing waste. The partnership activities include:

a. Conduct training and supervision of the performance of waste management carried out by other parties; b. Providing technical assistance to sub-districts, villages, and community groups in waste management by reusing garbage to be reused;

c. Determine and provide locations for Temporary Shelter (TPS), Integrated Waste Processing Site (TPST), and / or Final Disposal Site (TPA) that is safe and environmentally friendly [27].

d. Prepare master plan documents and feasibility studies on household waste management and similar household waste that includes: restrictions on waste generation, waste recycling, waste reuse, waste segregation, garbage collection, garbage transportation, garbage processing, garbage processing, final waste processing; and funding. The master plan for which the designation is intended for a period of at least 10 (ten) years.

e. Providing TPS in locations that are the source of rubbish or the origin of rubbish for sorting and garbage collection to facilitate the transportation of rubbish so that it can do the processing or final processing of rubbish. These locations include: residential areas, commercial areas, social facilities, public facilities and public roads.

f. Carrying out the process of reducing waste can be started from reducing the production of goods for human needs by producers based on plastic and producing more goods that can be used for a long time. Then also reducing the consumption patterns of disposable plastic goods by consumers and using goods that are more environmentally friendly including reusable, recyclable, and easily biodegradable.

g. Providing waste sorting sites based on the type of waste consisting of: garbage containing hazardous and toxic materials as well as hazardous and toxic waste materials, garbage that is easily biodegradable, garbage that can be reused, garbage that can be recycled.

h. Establish transportation and collection schedules.

i. Supervise the transportation of rubbish from the specified location in order to guarantee the segregation of rubbish according to the type of rubbish by using garbage transportation equipment that must meet safety, environmental health, comfort and hygiene requirements:

1) household waste to the TPS is the responsibility of the waste manager formed by the RT / RW;

2) waste from TPS to TPA is the responsibility of the regional government;

3) solid waste from residential areas, commercial areas, industrial zones, special zones, from the source of waste to the TPS and TPA, is the responsibility of the area manager;

4) Waste from public facilities, social facilities, and other facilities from the source of waste and / or TPS to the TPA, is the responsibility of the regional government.

The form of waste management that is mostly carried out in Indonesia is a centralized pattern, with the implementation of an open dumping system in the landfill (this pattern must be abandoned no later than 2013. as mandated by Law.18 / 2008 on Waste Management) [25].

Basically, waste management in Ambon City is managed in general by the local government, in this case the Ambon City Environment and Solid Waste Office with the processing carried out at the Integrated Waste Management Installation (IPST) [28] located in the landfill site located in Toisapu, 
AmaOry Village. The waste that is managed there are rubbish originating from the TPS located in the residential area, commercial area, social facilities, public facilities and public roads. Based on the author's research results in several polling stations in the area of the source of the waste, almost all the waste that is disposed of does not go through a waste sorting system [29]. So that when the garbage is transported to the landfill site, it will increase the amount of waste pile and prolong the processing time [10]. Waste management must be based on the types of waste because each type of waste has different ways of managing it so that if the garbage is taken to the TPA without sorting the waste at the TPS, the waste that has reached the TPA must go through the sorting process first. For IPST itself, there are two ways to manage waste, namely the first through the Recycling and Composting stages.

Recycling is done by the officers separating waste such as plastic waste that is still intact in shape to be recycled so it can be reused. Forms of management such as forming a craft or by using ecobricks techniques.Ecobricks is processing plastic waste into environmentally friendly materials [30]. This is an effort to reduce the accumulation of plastic waste. The environmentally friendly material is made by inserting and compacting clean and dry plastic waste into used plastic bottles and using a small stick to condense plastic waste into the bottle, the results of the ecobrickc can be combined each bottle and become a chair or table that can be used [31]. Meanwhile, through composting, which is easily decomposed waste can be made into compost. Compost can be used in agriculture and can also be made as fuel.

The Department of Environment and Solid Waste also experiences difficulties in transporting waste from TPS because the volume of waste has increased every day. The increase in garbage is inseparable from the increasing population of Ambon city which is increasing in number. In addition, economic growth and services such as hotels and restaurants, shopping centers that produce plastic waste and household waste are increasingly added to the non-compliance time that has been determined to the polling station, these things make it difficult for officers in terms of transporting waste, especially vehicles that are still less to transport waste from all polling stations. Not only that the increase in the amount of waste is also difficult for management because the management of waste in IPST is still small scale and the garbage is continuously transported to IPST so that the garbage keeps piling up especially if the garbage is mixed and some types of garbage are difficult to decompose.

The process of managing plastic packaging beverage waste can also be in the form of the destruction of the packaging using environmentally friendly technology that is technology that can reduce waste generation since the beginning of the production process. This means that the packaging that will be destroyed will not cause any more waste and after it is destroyed and then made into a product, the product will easily decompose. The packaging that has been destroyed can use the Ecobrick system which is more environmentally friendly.

Ambon city producers in their responsibility through waste management can recall packaging that has been consumed by consumers so that it can be recycled systematically through the information label specified on the packaging and determining the location of packaging returns

\section{CONCLUSION}

Based on the description in this paper, it can be concluded that the implications of the responsibility of Ambon city producers in Waste Management for plastic packaging beverage products based on Law Number 18 Year 2008 Regarding Waste Management are that producers must withdraw packaging that has been consumed by consumers in order to be recycled systematically, thoroughly and continuously re-produce and produce goods using environmentally friendly and reusable materials. The packaging retraction process can be in the form of a notification given by the manufacturer to sales places such as supermarkets or large supermarkets such as at Hypemart in Maluku City Mall (MCM) and Ambon City Center (ACC) to then notify consumers to collect waste from products plastic packaging drinks purchased and the party from the manufacturer and the person in charge of the supermarket or large supermarket that provides a temporary collection place.

After doing so, it can restore good environmental functions, reduce the amount of plastic beverage packaging waste every day, and also prevent environmental pollution caused by the plastic packaging beverage waste.

In addition to doing this, the producer in charge of waste management can partner with the Ambon city government as contained in Article 44 paragraph (1) of the Ambon City Regulation which covers the provision / construction of Temporary Shelter (TPS) or TPS 3R (Reduce Reuse, Recycling), Final Disposal Site (TPA) or Integrated Waste Processing Site (TPST), and supporting facilities and infrastructure in this case providing waste transportation vehicles from TPS or TPS 3R to TPA or TPST, TPA or TPST management and / or processed product management the other. The partnership is in the form of sorting, collecting, transporting, processing and / or final processing of waste.

\section{REFERENCES}

[1] Undang-Undang Nomor 32 Tahun 2009 tentang Perlindungandan Pengelolaan Lingkungan Hidup. Lembaran Negara Republik Indonesia Tahun 2009 Nomor 140. https://www.jogloabang.com/pustaka/uu32-2009-perlindungan-pengelolaan-lingkungan-hidup.

[2] Hadiwiyoto, S. (1983). Penanganandan Pemanfaatan Sampah. YayasanIdayu, Jakarta. https://opac.perpusnas.go.id/DetailOpac.aspx?id=18361

[3] Kustiasih, T., dan Aryenti, S.D. (2017). Penerapan teknologi pengolahan sampah di kawasan wisata pantai. Jurnal Pusat Litbang Perumahan dan Pemukiman, 4(3).

[4] Tchobanoglous, G.T., Vigil, D.S.A., (1993). Integrated Solid Waste Mangement Engineering Principles and Mangement Issues. Mc. Grw Hill, Singapore.

[5] REPOBLIKA Sampah adalah Tanggung Jawab Produsen.

https://www.republika.co.id/berita/nasional/umum/16/0 2/22/o2xh0f282-sampah-adalah-tanggung-jawabprodusen, diakses tanggal, accessed on April 30, 2020.

[6] Sucipto, C.D. (2012). Teknologi Pengolahan Daur Ulang Sampah, Goysen Publishing, Jakarta. http://gosyenpublishing.web.id/?product=teknologipengolahan-daur-ulang-sampah.

[7] CNN Indonesia Penyumbang Sampah Plastik Terbesar Ke-dua Dunia. https://www.cnnindonesia.com/gayahidup/20160222182308-277-112685/indonesiapenyumbang-sampah-plastik-terbesar-ke-dua-dunia, diakses tanggal, accessed on April 30, 2020. 
[8] Suwerda, B. (2012). Bank Sampah: Kajian Teoridan Penerapannya, Pustaka Rihama, Yogyakarta.

[9] Peraturan Pemerintah Nomor 81 Tahun 2012 Tentang Pengelolaan Sampah Rumah Tanggadan Sampah Sejenis Sampah Rumah Tangga. Lembaran Negara Republik Indonesia Tahun 2012 Nomor 188. https://peraturan.bpk.go.id/Home/Details/5295/pp-no81-tahun-2012.

[10] Wildawati, D. (2019). Aktor yang berhubungan dengan pengelolaan sampah rumah tangga berbasis masyarakat di kawasan bank sampah hanasty kota solok. Human $\begin{array}{lll}\text { Care } & \text { Journal, } & \text { 4(3): }\end{array}$ http://dx.doi.org/10.32883/hcj.v4i3.503

[11] Marzuki, P.M. (2017). Penelitian Hukum Edisi Revisi. Prenada Media, Jakarta. https://books.google.co.id/books?hl=en\&lr=\&id=CKZA DwAAQBAJ\&oi=fnd\&pg=PA1\&dq=info:Pu8ObaCJK EMJ:scholar.google.com\&ots $=$ mmHviY8eTF\&sig $=x g x$ MfCKN9GjDz7uzlTWo5GzdaFU\&redir_esc=y\#v=onep age \&q\&f=false.

[12] Abrar (2014). Hukum Pertambangan. Universitas Islam Indonesia Yogyakarta Press.

[13] Horizon, Spatial Planning, Tourism, Disaster, Religion, Self Defense, Sustainable Urban Development. https://fitriwardhono.wordpress.com/2012/04/14/pemba ngunan-kota-berkestari/ accessed on July 7, 2020.

[14] Hardjasoemantri, K. (2018). Hukum Tata Lingkungan: Edisi ke-8. GadjahMada University Press, Yogyakarta. https://ugmpress.ugm.ac.id/id/product/lingkungan/huku m-tata-lingkungan-edisi-ke-8,

[15] Eko, B. (2005). Jurnal Kota Berkelanjutan. Bandung: PT. Alumni.

[16] Angga, L.O., Saptenn, M.J. (2019). The formulation of green open space in the regional regulation of spatial planning of Maluku Province. International Journal of Scientific \& Technology Research, 8(10): 3370-3375.

[17] MONGABOY Situs Berita Lingkungan, Penanganan Sampah Perlu Paradigma Baru. https://www.mongabay.co.id/2019/07/24/penanganansampah-perlu-paradigma-baru/ diakses tanggal, accessed on April 30, 2020.

[18] Erwin, M. (2015). Hukum Lingkungan (dalam Sistem Perlindungan dan Pengelolaan Lingkungan Hidup Di Indonesia). RefikaAditama, Bandung.

[19] Muchtar, M. (2016). Hukum Kesehatan Lingkungan, (Kajian Teoritisdan Perkembangan Pemikiran). PustakaBaru Press, Yogyakarta.

[20] Supardi, I. (2003). Lingkungan Hidup \& Kelestariannya. PT, Alumni, Bandung. https://onesearch.id/Record/IOS3605.INLIS000000000
019242

[21] Peraturan Daerah Kota Ambon Nomor 11 tahun 2015 Tentang Pengelolaan Sampah. Lembaran Daerah Kota Ambon Tahun $2015 \quad$ Nomor 11. https://peraturan.bpk.go.id/Home/Details/11709/perdakota-ambon-no-11-tahun-2015.

[22] Peraturan Menteri Lingkungan Hidup Republik Indonesia Nomor 7 Tahun 2014 Tentang Kerugian Lingkungan Hidup Akibat Pencemarandan/atau Kerusakan Lingkungan Hidup. Berita Negara Republik Indonesia Kementerian Lingkungan Hidup Nomor 1726 Tahun 2014. https://m.hukumonline.com/pusatdata/detail/1t5465ce52 $\mathrm{d} 35 \mathrm{~d} 2 /$ peraturan-menteri-lingkungan-hidup-nomor-7tahun-2014/history.

[23] Ashabul, K. (2017). Tinjauan terhadap pengelolaan sampah. Jurnal Jurisprudentie, 4(1).

[24] Inspirasi Hukum. http://inspirasihukum.blogspot.com/2011/04/pertanggun gjawabanadministrasi-negara_23.html, diaksestanggal, accessed on April 30, 2020.

[25] Undang-Undang Nomor 18 Tahun 2008 tentangPengelolaanSampah.Lembaran Negara Republik Indonesia Tahun 2008 Nomor 69. https://peraturan.bpk.go.id/Home/Details/39067/uu-no18-tahun-2008.

[26] ANTRA MALUKU 70 persen sampah teluk Ambon didominasi plastik. https://ambon.antaranews.com/berita/50702/70-persensampah-teluk-ambon-didominasi-plastik https://ambon.antaranews.com/berita/50702/70-persensampah-teluk-ambon-didominasi-plastik diakses tanggal, accessed on April 30, 2020.

[27] Suryani, A.S. (2014). Peran bank sampah dalam efektivitas pengelolaan, sampah (studi kasus bank sampah malang). Jurnal Masalah-masalah Sosial, 5(1). https://doi.org/10.46807/aspirasi.v5i1.447

[28] Hendra, Y. (2016). Perbandingan sistem pengelolaan sampah di indonesia dan korea selatan: Kajian 5 aspek pengelolaan sampah. Aspirasi, 7(1). https://doi.org/10.46807/aspirasi.v7i1.1281

[29] Kartikawan, Y. (2017). Pengelolaan Persampahan. Yogyakarta: Jurnal Lingkungan Hidup.

[30] Haeruman. (1979). Perencanaandan Pengelolaan Lingkungan Hidup. Bogor: SekolahPascasarjana IPB.

[31] Arif Nr, Artikel Pengelolaan Sampah. https://www.scribd.com/doc/306784537/ArtikelPengelolaan-Sampah diakses tanggal, accessed on April 30, 2020. 